\title{
348. 胸部用フィルム撮影条件の最適化
}

安城更生病院 放射線技術科 ○沢田道人 鈴木炤弘柘植達矢 栗田敦子 天野敦之 山中由紀

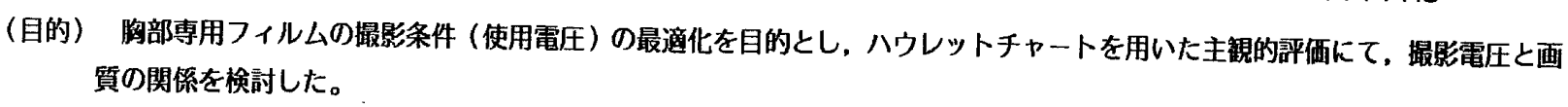

（万法）使用フィルム‥HR-S (慓隼タイプ), HR-C, MGC (胸部タイプ)

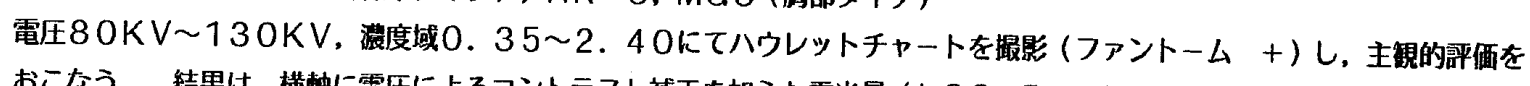

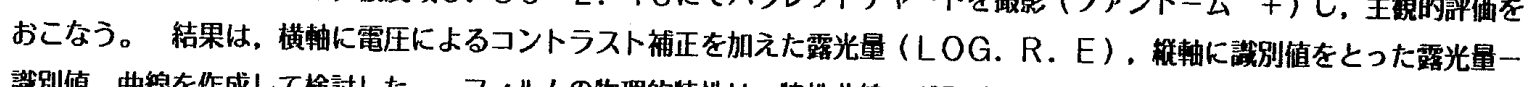

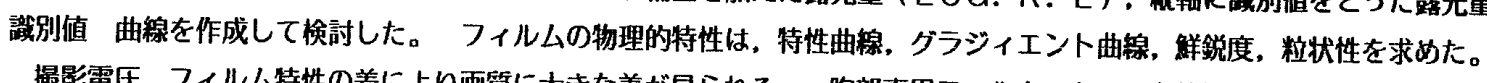

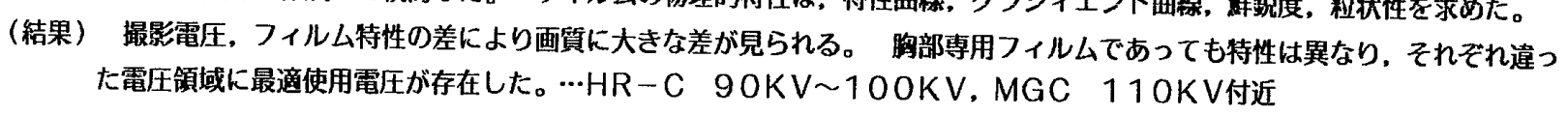

349. HRC（胸部用フィルム）の一般撮影への応用

済生会下関総合病院 $O$ 米北浩一郎 破山明一杉原広頼 前平 晃 竹之内光昭 松木純一 谷村 明 福嶋民子辻野幸代 富士メディカルシステム（株）松延 敏

【目的】胸部専用フィルムとして開発されたHRCであるが、ワイドラチュードのため、肺野部のコントラス 卜が低い特性を持つ。今回我々は、このHRCのラチュードの広さに着目し、X 線吸収差の大きな他の部位への、

【方法】当院での、HRCの臨床応用は、(1)耳下腺造影 (2)肩関節撮影 (3)年骨撮影 (4)咽喉頭撮影 (5)胎児

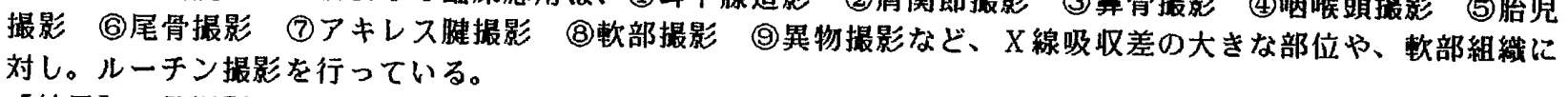

【結果】骨撮影において、軟部組織から骨までの診断域の拡大と、フィルター等を必要としないため、撮影の 简便性や省力性が計られた。これにより、むしろHRCは、胸部以外への適応性が大きく認められた。

350．試作高鮮鋭度微粒子シネフィルムの諸特性と臨床使用への有用性

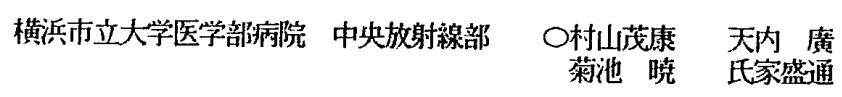

[目的］高鮮鋭度微柆子シネフィルムの試呀使用の機会を得たので、その諸特性と臨床使用への有用性について検討する。

[万法］現像温度、現像処理スピード、現像液を違文特性曲線の变化を調へた。 徉来フィルムとの比較を物理的評価（MTF，RMS）と視覚的評洒（ROC曲線）について行った。

[結果] 従来フィルムよりMTF，RMSは向上していた。

特性曲線は、現像処理条件を量えても階調か変化せず、感度のみ変化するという特徽を有していた。

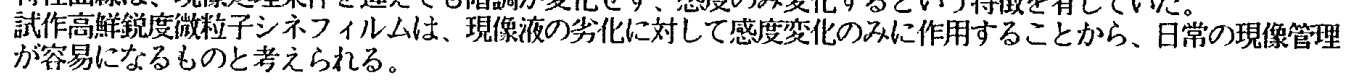

351. シネフィルムKodak CFT の臨床的有用性 大分医科大学附属病院 ○三和秋雄 山内徽 小石幸生 コダックナガセ 伊知地宏志岡村榗一

（目的） T粒子技術およで色素技術等により、その鮮鋭度が大幅に向上したシネフィルム KodakCFTが 、あらたに発売された。わ㹝れは、この「超高鮮鋭度タイプシネフィルムKodak CFT」を臨本に使用 し、その有用性について辞価, 検討を行った。

(方法) 高鮮鋭度シネフィルムCF' VARI, MI - CFについて、物理的諸特性および臨床的有用性の評価を行った。

(結果) シネフィルムKodak CFTを踟床に使用する機会を得たが、このフィルムの使用により、その画 質（特に、鮮鋭度）が、大幅に向上した。また、同時に行った物理的諸特性を知るための各基硶実験 においても、ほ汪同様の結果が得られた。

以上より、われわれは、超高鮮鋭度タイプシネフィルムKodak CFTは、蹦床上敕めて有用と考えている。 